\title{
The Effect of Two-Mile Jogging Training on Lung Function Values in TNI Soldier Kodam I/Bukit Barisan
}

\author{
Rifda Hayati ${ }^{1 *}$, Nuryunita Nainggolan ${ }^{1}$, Amira Permatasari Tarigan ${ }^{1}$, Putri \\ Chairani Eyanoer² \\ ${ }^{1}$ Department of Pulmonology and Respiratory Medicine Faculty of Medicine, \\ Universitas Sumatera Utara, RSUP H Adam Malik, Medan \\ ${ }^{2}$ Department of Community Medicine Faculty of Medicine, Universitas Sumatera Utara, Medan
}

\section{ABSTRACT}

Background: Military soldiers are army personnel who are required to have good physical endurance and optimal fitness, include. So, it's needed physical exercise, include to be able to improve lung function. One parameter that can reflect physical fitness are lung function and $\mathrm{VO}_{2}$ max. This study aims to determine whether there is a relationship between physical exercise in the form of 2-mile jogging with increased lung function and $\mathrm{VO}_{2}$ max of military soldiers Kodam I Bukit Barisan

Methods: This research is an experimental study carried out in February-April 2019 against the TNI soldiers of the Bukit Barisan Military District I. The research subjects were divided into two groups, group 1 who underwent regular 2-mile jogging exercises 3-5 times a week with a duration of 25 minutes for 2 months, and group 2 who underwent non-routine jogging exercises (less than 3 times a week). Lung function was assessed by spirometry.

Results: As many as 68 military soldiers were involved in this study which were divided into two groups, 38 people in the group 1 who routinely trained and 30 people in group 2 that did not routinely practice. Group $1 \mathrm{FEV}_{1}$ values were higher than group $2(\mathrm{P}=0.03)$. No significant differences in terms of FVC, MVV and VO2max in both groups. Lung function of smokers were lower than non-smokers, but not statistically significant.

Conclusion: There were significant differences in $\mathrm{FEV}_{1}$ values between military soldiers who routinely and did not routinely undergo 2-mile jogging exercises.

Keywords: jogging exercise, spirometry, lung function

*Correspondence: Rifda Hayati - rifdahayati15041980@gmail.com

Submitted: September $13^{\text {th }} 2020$, Accepted: October 25th 2020, Published: October $31^{\text {st }} 2020$ 


\section{INTRODUCTION}

Indonesian National Army Soldiers (TNI) are army personnel prepared for military careers to ensure the security of military organizations and communities. To carry out his duties, a Soldier of the TNI demands to have good physical endurance and optimal fitness (physical fitness). The essential elements in physical fitness are cardiorespiratory endurance, which is the ability of the heart and lungs and blood vessels to function optimally in a state of rest as well as exercise for taking in oxygen and then distribute it to tissues in the metabolic processes of the body. ${ }^{1}$

One way to assess fitness in physical activity is to measure the value of pulmonary function and maximum oxygen capture value or $\mathrm{VO}_{2}$ max. Physical exercise is essential for maintaining and improving physical fitness. Aerobic physical exercise is able to optimize heart performance to increase blood capacity to transport and distribute oxygen to tissues to meet metabolic needs. ${ }^{1,2}$

This form of jogging exercise is one of the aerobic exercises that has been validated to assess the cardiovascular endurance of healthy people $^{3}$, who in this case are TNI soldiers. This research aims to find out whether there is a relationship between physical exercise in the form of jogging with increased lung function and uptake maximum oxygen to the soldiers of the TNI Kodam I Bukit Barisan.

\section{METHOD}

This research is an experimental study design with two group pretestposttest conducted in February - April 2019. The research subject is the soldier TNI Kodam I Bukit Barisan, which is distinguished into 2 groups which taken by using a consecutive sampling technique.

Group 1 is a TNI soldier who undergoes regular training. The form of exercise is jogging $3-5$ times a week, with a duration of 25 minutes/training session. The training program is carried out for 2 months. As for the group 2 is TNI soldiers who undergo regular training, which is less than 3 times a week.

Measurement of lung function and maximum oxygen capture value is done before and after the exercise program. Lung function is measured through spirometry examination using two manoeuvres, namely FVC manoeuvres, to obtain $\mathrm{FEV}_{1}, \mathrm{FVC}$ and $\mathrm{FEF}_{1} / \mathrm{FVC}$ values. A second manoeuvre follows the examination, the MVV manoeuvre to get an MVV value that represents the strength of the breathing muscles. 
Table 1. The Characteristic of the Subject

\begin{tabular}{|c|c|c|c|c|c|}
\hline \multirow{2}{*}{ Characteristics } & \multicolumn{2}{|c|}{ Routine } & \multicolumn{2}{|c|}{ Not Routine } & \multirow{2}{*}{ P* } \\
\hline & $\mathbf{n}$ & $\%$ & $\mathbf{n}$ & $\%$ & \\
\hline \multicolumn{6}{|l|}{ Gender } \\
\hline Male & 38 & 100.0 & 27 & 100.0 & \multirow[t]{2}{*}{---} \\
\hline Female & 0 & 0.0 & 0 & 0.0 & \\
\hline \multicolumn{6}{|l|}{ Age } \\
\hline$<40$ old & 37 & 97.4 & 15 & 55.5 & \multirow[t]{2}{*}{$<0.01$} \\
\hline$\geq 40$ old & 1 & 2.6 & 12 & 45.5 & \\
\hline \multicolumn{6}{|l|}{ BMI } \\
\hline Underweight & 0 & 0.0 & 0 & 0.0 & \multirow{4}{*}{0.17} \\
\hline Normoweight & 12 & 31.6 & 4 & 14.8 & \\
\hline Overweight & 11 & 28.9 & 9 & 33.3 & \\
\hline Obese & 15 & 39.5 & 14 & 51.8 & \\
\hline \multicolumn{6}{|l|}{ Cigarette } \\
\hline No Smoking & 17 & 44.7 & 16 & 59.3 & \multirow{4}{*}{0.34} \\
\hline Low & 7 & 18.4 & 4 & 14.8 & \\
\hline Medium & 14 & 36.8 & 7 & 25.9 & \\
\hline High & 0 & 0 & 3 & 10 & \\
\hline \multicolumn{6}{|l|}{$\% \mathrm{FEV}_{1}$} \\
\hline$\geq 80$ & 16 & 42.1 & 12 & 45.5 & \multirow{4}{*}{0.88} \\
\hline $50-79$ & 22 & 57.9 & 15 & 55.5 & \\
\hline 3049 & 0 & 0.0 & 0 & 0.0 & \\
\hline$<30$ & 0 & 0.0 & 0 & 0.0 & \\
\hline \multicolumn{6}{|l|}{$\% F V C$} \\
\hline$\geq 80$ & 20 & 52.6 & 13 & 48.1 & \multirow{4}{*}{0.51} \\
\hline $50-79$ & 18 & 47.4 & 14 & 52.9 & \\
\hline $30-49$ & 0 & 0.0 & 0 & 0.0 & \\
\hline$<0$ & 0 & 0.0 & 0 & 0.0 & \\
\hline \multicolumn{6}{|l|}{$\% \mathrm{FEV}_{1} / \mathrm{FVC}$} \\
\hline$\geq 75$ & 38 & 100.0 & 27 & 100.0 & \multirow[t]{2}{*}{---} \\
\hline$<75$ & 0 & 0.0 & 0 & 10.0 & \\
\hline \multicolumn{6}{|l|}{$\% M V V$} \\
\hline$\geq 80$ & 2 & 5.3 & 2 & 7.4 & \multirow{3}{*}{0.82} \\
\hline $50-79$ & 28 & 73.7 & 19 & 70.3 & \\
\hline $30-49$ & 8 & 21.1 & 6 & 22.2 & \\
\hline
\end{tabular}

Note: $\left(^{*}\right)$ Test Chi Squared. BMI=Body Mass Index, $\mathrm{FEV}_{1}=$ First second forced expiration volume, FVC=Forced vital capacity, MVV=Maximal Voluntary Ventilation. 
This formula has been shown to have a good level of accuracy to measure the value of maximum oxygen uptake in a healthy Indonesian population. Pulmonary function treatment is carried out before and after the training program for 2 months. The data obtained is then done statistical analysis with a different mean test using statistical package for social sciences (SPSS) software where the value of $P<0.05$ is stated to mean.

\section{RESULT}

A total of 68 TNI soldiers were involved as subjects in this study, which was distinguished into two groups, namely a group with a jogging routine of 38 people, and a group that underwent a non-routine jogging exercise of 30 people. All research subjects are male.

The characteristics of this study subject can be seen in Table 1 . The preliminary examination results of the lung function of both groups can be seen in Table 2. It can be seen that there was a significant difference in $\mathrm{FEV}_{1} / \mathrm{FVC}$ scores at the beginning of the study between the two groups, where the group that did not regularly undergo exercise had a lower $\mathrm{FEV}_{1} / \mathrm{FVC}$ score than the group that was a regular exercise. However, $\mathrm{FEV}_{1} / \mathrm{FVC}$ values in both groups are still within the normal value range $(>75 \%)$.

Table 2. The results of the examination pulmonary function before the exercise (Baseline)

\begin{tabular}{lccc}
\hline \multirow{2}{*}{ Parameters } & \multicolumn{2}{c}{ Mean \pm SD } & P \\
\cline { 2 - 3 } Before Exercise & Routine & Not Routine & \\
FEV $_{1}(\%)$ & $78.2 \pm 8.33$ & $74.9 \pm 9.27$ & 0.12 \\
FVC (\%) & $78.7 \pm 8.06$ & $76.4 \pm 10.3$ & 0.3 \\
FEV $/$ FVC (\%) & $82.2 \pm 4.35$ & $79.3 \pm 4.69$ & $0.01^{*}$ \\
MVV (\%) & $57.1 \pm 11.9$ & $57.1 \pm 12.0$ & 0.98 \\
After Exercise & & & \\
FEV $(\%)$ & $78.7 \pm 8.3$ & $74.9 \pm 7.7$ & $0.04 *$ \\
FVC (\%) & $78.9 \pm 6.5$ & $76.2 \pm 7.9$ & 0.12 \\
FEV 1 FVC (\%) & $82.2 \pm 6.1$ & $81.3 \pm 4.3$ & 0.08 \\
MVV (\%) $_{\text {VO }}$ (\%) & $59.7 \pm 11.2$ & $58.8 \pm 15.3$ & 0.69 \\
\hline
\end{tabular}

Note: $\left({ }^{*}\right) \mathrm{T}$ Independence test, $\mathrm{FEV}_{1}=$ First second forced expiration volume, $\mathrm{FVC}=$ Forced vital capacity, $\mathrm{MVV}=$ Maximal Voluntary Ventilation 
All subjects performed aerobic exercises in the form of jogging for 2 months. Group 1 did jog 3 - 5 times a week, with a duration of 25 minutes/training session, while group 2 did less than the amount of physical exercise, and was grouped as a nonroutine group. After the 2-month training program is completed, pulmonary faal examination and max $\mathrm{VO}_{2}$ assessment are carried out on all research subjects with the following results.

Table 2 shows that there is a significant difference in FEV1 values and $\mathrm{FEV}_{1} / \mathrm{FVC}$ values between groups undergoing regular jogging exercises and those who did not routine $(P<0.05)$. The group who regularly underwent exercise had higher $\mathrm{FEV}_{1}$ and $\mathrm{FEV}_{1} / \mathrm{FVC}$ scores compared to those who did not exercise regularly. However, there are no significant differences in terms of FVC, MVV or $\mathrm{VO}_{2} \max$.

\section{DISCUSSION}

Physical exercise is defined as body movements produced by skeletal muscles that cause energy to be used. Physical activities in daily life can be categorized into work, sports and daily activities. Exercise is a part of physical activity that is planned, structured and repetitive and has the ultimate goal of improving or maintaining physical fitness ${ }^{4}$. Many studies recommend treadmill aerobic exercise or jogging as a way to maintain or improve lung function ${ }^{5}$.

Physical exercise will cause your muscles to get stronger. Improvement in muscle function is found, especially the respiratory muscles and will cause breathing to be more efficient, especially at rest. Pulmonary ventilation in people who regularly exercise and people who don't exercise is the same, but people who regularly exercise can breathe more slowly and deeply. This causes the oxygen needed for muscle work in the ventilation process to decrease so that with the same amount of oxygen, the respiratory muscles of people who regularly exercise will work more effectively ${ }^{6}$.

In one study, 6790 subjects were followed for 19 months. Those undergoing regular physical exercise showed $50 \mathrm{ml}$ increases in $\mathrm{FEV}_{1}$ and 70 $\mathrm{ml}$ in CVP; In contrast, subjects who rarely exercised had a $30 \mathrm{ml}$ decrease in $\mathrm{FEV}_{1}$ and a $20 \mathrm{ml}$ decrease in CVP. These findings are consistent with other studies, which suggest that $\mathrm{FEV}_{1}$ improvements are mainly due to the expansion of the lungs during highintensity aerobic exercise, resulting in a greater volume of air being introduced into the airways and widening of the airways $^{5}$. This study also found the 
same thing. There was a significant increase in the $\mathrm{FEV}_{1}$ value in the group who routinely underwent jogging exercise compared to those who did not exercise regularly $(78.7 \%$ vs $74.4 \%$; $\mathrm{P}<0.05)$.

The results obtained in this study are slightly different from the findings of Rawashdeh et al. This study showed that there was no significant difference between the group who regularly exercised and those who did not regularly (59.7\% vs $58.4 \% ; \mathrm{P}=0.71$ ). The difference in the results of this study could occur because the TNI soldiers who were the sample of the study were healthy people, so the difference in the effect of training was not as straightforward as those found in patients with COPD. 6,7

$M V V$ is a measure of the performance of the respiratory muscles. The increase in MVV after exercise can be due to the increase in respiratory muscle development associated with physical activity. MVV elevation without an increase in CVP indicates the effect of exercise on the respiratory muscles occurring without an increase in large or small airways because MVV is less affected by the state of the airways than other parameters. A higher exercise intensity or longer duration may be required to influence pulmonary function parameters such as CVP and MVV8.

\section{CONCLUSION}

There is a significant difference in the $\mathrm{FEV}_{1}$ value between TNI soldiers who routinely and do not routinely undergo jogging training. There is no relationship between jogging exercise and the FVC and MVV values.

\section{REFERENCES}

1. Campos LCB, Campos FAD, Bezerra TAR, Pellegrinotti ÍL. Effects of 12 Weeks of Physical Training on Body Composition and Physical Fitness in Military Recruits. International journal of exercise science. 2017;10(4):560567.

2. Santtila $M$, Häkkinen $K$, Kraemer WJ, Kyröläinen H. Effects of basic training on acute physiological responses to a combat loaded run test. Military Medicine. 2010;175(4):273-279.

3. Sporiš G. Validity of 2-miles run test for determination of VO 2 max among soldiers. J Sport Human Perf. 2013;1(1):15-22.

4. Spruit MA, Burtin C, De Boever $P$, et al. COPD and exercise: does it make a difference? Breathe. 2016;12(2):e38-e49.

5. Rawashdeh A, Alnawaiseh N. The 
effect of high-intensity aerobic exercise on the pulmonary function among inactive male individuals. Biomedical and Pharmacology Journal. 2018;11(2):735-741.

6. Yunus F. Faal Paru dan Olahraga. J Respir Indo. 1997;17(2):100105.

7. Amira P. Tarigan. Ilmu Dasar Faal Paru. Medan: Program Studi Pulmunologi dan IImu Kedokteran Respirasi, Fakultas Kedokteran Universitas Sumatera Utara; 2016.

8. Santtila M, Hä Kkinen Keijo †;, Laura K, Kyrö Lä Inen Heikki ; Changes in Cardiovascular Performance during an 8-Week Military Basic Training Period Combined with Added Endurance or Strength Training. Military Medicine. 2008;173:1173. 